\title{
Teaching Academic English to Russian-speaking Academic Staff: The Case of the Office of Academic Writing
}

Marina A. Chernysheva - Cand. Sci. (Philology), Assoc. Prof. at the Department of Linguistics and Translation, Teacher of academic writing courses, e-mail: chernyshevama@susu.ru

Anna O. Kozlova - Teacher at the Department of Russian as a Foreign Language, Teacher of academic writing courses, e-mail: kozlovaao@susu.ru

Evgeniya V.Donova - Admin. at the Office of Academic Writing, e-mail: donovaev@susu.ru

South Ural State University (National Research University), Institute of Linguistics and International Communication, Chelyabinsk, Russia

Address: 76, Lenin prospekt, Chelyabinsk, 454080, Russian Federation

Abstract. The paper discusses the preliminary results of teaching academic writing to scientific and academic staff at South Ural State University (national research university) within the framework of advanced training courses. The 36- and 72-hour training programs were developed by the academic and methodological department of the Office of Academic Writing. The Office was opened at the university in 2016 in order to improve the academic literacy of the university's academic staff, develop professional communication skills in English, and assist authors who aspire to get their papers published in top rated scientific journals indexed in the scientific citation databases Scopus and Web of Science. Upon completion of these programs, authors of scientific papers gain knowledge about the basics of academic writing, the structure of a scientific paper, the English scientific style and its lexical and grammatical features, as well as editing a paper, working with scientific citation databases, and elaborating a publishing strategy. We conducted a study from October 2016 to December 2018 and calculated data on the attendees' affiliation (an institute or higher school), the contingent (position), and the importance of the offered training programs (the number of attendees in each course). The obtained data indicates that representatives of social-humanitarian and technical fields show a special interest in the courses. The courses of academic writing are most popular among associate professors who have experience in publishing papers in Russian. Authors are especially interested in intensive practice-oriented programs. Upon completion of the courses and with the support of the Office of Academic Writing, attendees prepared scientific texts in English and submitted them to top rated journals and conference proceedings. The educational activity of the Office of Academic Writing can be developed through elaboration and implementation of new advanced training programs, including the distance ones. Their effectiveness will be evaluated by an increase in the publication activity of the university's employees.

Keywords: academic writing, publication activities, scientific papers in English, citation databases, Scopus, Web of Science

Cite as: Chernysheva, M.A., Kozlova, A.O., Donova, E.V. (2019). Teaching Academic English to Russian-speaking Academic Staff: The Case of the Office of Academic Writing. Vysshee obrazovanie $v$ Rossii = Higher Education in Russia. Vol. 28, no. 10, pp. 50-57. (In Eng., abstract in Russ.)

DOI: https://doi.org/10.31992/0869-3617-2019-28-10-50-57

\section{Introduction}

In recent years, academic writing skills have been highly demanded in the area of applied sciences and methodological work in the Russian higher education. Centers for academic writing have been opened in different cities of Russia (Moscow, Samara, Tyumen, Chelyabinsk); their purpose is to develop researchers' competences 
that are necessary for successful written communication in the international scientific and academic environment. In 2016, experts in academic writing and managers of Russian leading universities' centers founded the Russian Writing Centers Consortium (RWCC). The consortium aims not only to coordinate the work of the centers for academic writing in Russia, but also to guide them in integrating academic writing into the system of Russian education and spreading Russian scientific ideas in the international scientific community $[1 ; 2]$.

The work of centers for academic writing in Russia is organized by the leading universities in the framework of Project 5-100. The key idea of this project is to maximize the competitive position of the leading Russian universities in the global scientific and academic community. To achieve this goal, it is important to encourage foreign publication activities of academic staff, and in particular, to increase the number of publications in journals indexed in the scientific citation databases Scopus and Web of Science [3].

While the issue of academic writing in English is a relatively new area of research and application in the Russian academic community, it has been developed for many years in foreign countries. The number of publications devoted to the specifics of teaching academic writing to graduate and postgraduate students is growing steadily. Thus, scientific journals and proceedings of international conferences discuss general theoretical and practical issues of teaching academic writing [4], the issue of the cultural component in academic writing and its integration in the context of intercultural dialogue $[5 ; 6]$, the experience of applying new technologies in teaching academic writing, in particular Internet tools [7], etc.

\section{Functioning of the educational section} of the SUSU Office of Academic Writing

The Office of Academic Writing (OAW) of South Ural State University (SUSU) was opened in October 2016 and is a structural unit of the Institute of Linguistics and International Com- munication (ILIC). While the Office works within the framework of the Project 5-100 strategies, it aims to address the issues related to improving authors' academic literacy and their writing of scientific articles for top rated foreign scientific editions.

The OAW functions due to the interaction of 4 sections: the administrative, counseling, translating, and educational ones. Within the framework of the educational section, academic writing programs are being developed and implemented according to the international requirements for authors' publication activities. The 36- or 72-hour programs of the academic writing courses were developed on the basis of modern Russian and foreign textbooks that help master the academic writing style and teach authors to orient themselves in scientific publications indexed by the scientific citation databases Scopus and Web of Science. Upon completion of the courses, attendees receive state-recognized certificates. Training is provided by the SUSU staff members who have completed courses and attended seminars on academic writing and have their own experience of foreign publication activities.

Apart from academic writing courses, the Office arranges training sessions and workshops assisted by leading experts in academic writing in English. An important element in informational and methodological support is the Office's official website: http://ilic.susu.ru/awo/

More detailed information on the structure and other aspects of OAW functioning was provided by M. Chernysheva, E. Nenakhova, and E. Donova [8]. Prospects of introducing online modules into the OAW educational activities and the specifics of training tutors were discussed by E. Nenakhova and Y. Seryapina [9; 10].

\section{Analysis of the demand for academic writing courses}

To monitor the Office's activity and develop a strategy for its further work, it is important to analyze the demand for academic writing courses among SUSU employees. 
We analyzed the demand for academic writing courses throughout the entire period from October 2016 to December 2018, i.e. from informing the university's employees about the courses until their enrollment in the selected courses. At the beginning of each semester, SUSU employees received an information letter offering them to study advanced training courses at the Office of Academic Writing. The course attendees received additional information about specific courses at personal meetings and via email. When providing attendees with further information, we found the following: attendees' choice of a particular program depended on the considered issues (the content of the program), their level of English, experience of publishing in international journals and conference proceedings, and the workload of the course.

We selected the following analysis criteria: affiliation of course attendees (affiliation with a Higher School or Institute), contingent (position) of course attendees, and the implemented training programs.

\section{Affiliation of the attendees of academic writing courses}

The SUSU structure comprises 12 institutes and higher schools of technical sciences, natural science, and humanities. These structural units resulted from the integration of faculties in 2016 that was made within the framework of the program 5-100. The rearrangement aimed to concentrate scientific knowledge within the key structural units.

During the analyzed period, 276 SUSU staff members completed academic writing courses organized by OAW teachers. Table 1 shows the data on the number of course attendees in descending order.

As Table 1 shows, the largest number of course attendees belongs to the Institute of Linguistics and International Communication (50 people), the School of Economics and Management (46 people), the Polytechnic Institute (37 people), and the School of Electrical Engineering and Computer Science ( 36 people). The courses appeared to be least demanded among
Table 1

The number of course attendees from the Higher Schools and Institutes

\begin{tabular}{|c|l|c|c|}
\hline № & \multicolumn{1}{|c|}{ School / Institute } & $\begin{array}{c}\text { Number } \\
\text { of people }\end{array}$ & $\%$ \\
\hline 1 & $\begin{array}{l}\text { Institute of Linguistics and } \\
\text { International Communication }\end{array}$ & 50 & 18,12 \\
\hline 2 & $\begin{array}{l}\text { School of Economics and } \\
\text { Management }\end{array}$ & 46 & 16,67 \\
\hline 3 & Polytechnic Institute & 37 & 13,41 \\
\hline 4 & $\begin{array}{l}\text { School of Electrical } \\
\text { Engineering and Computer } \\
\text { Sciences }\end{array}$ & 36 & 13,04 \\
\hline 5 & $\begin{array}{l}\text { Institute of Social Sciences and } \\
\text { Humanities }\end{array}$ & 32 & 11,59 \\
\hline 6 & School of Medical Biology & 22 & 7,97 \\
\hline 7 & Institute of Natural Sciences & 18 & 6,52 \\
\hline 8 & Institute of Law & 15 & 5,43 \\
\hline 9 & $\begin{array}{l}\text { Institute of Sport, Tourism and } \\
\text { Service }\end{array}$ & 8 & 2,90 \\
\hline 10 & $\begin{array}{l}\text { Institute of Architecture and } \\
\text { Construction }\end{array}$ & 7 & 2,54 \\
\hline 11 & Other Departments & 3 & 1,09 \\
\hline 12 & $\begin{array}{l}\text { Institute of Continuing } \\
\text { Education }\end{array}$ & 2 & 0,72 \\
\hline 13 & $\begin{array}{l}\text { Institute of Open and Distance } \\
\text { Education }\end{array}$ & 0 & 0 \\
\hline & Total, people & 100 \\
\hline
\end{tabular}

the staff of the Institute of Sport, Tourism and Service ( 8 people), the Institute of Architecture and Construction (7 people), other departments ( 3 people) and the Institute of Continuing Education ( 2 people).

The reason why the attendees from the Institute of Linguistics and International Communication are interested in academic writing courses can be explained by the fact that they already have sufficient knowledge of English, but would like to study the rules and principles of the academic style more deeply in order to follow them when writing their own articles, and also to apply these rules when translating scientific articles of their colleagues.

Presently, research in the economic field causes a great interest of the international scientific community. Therefore, increasingly more experts in economics are studying English, and academic writing in particular.

What is more, research in the field of energyefficient and resource-efficient technologies, 
Table 2 that these staff members also wish to continue

Contingent of attendees of academic writing courses

\begin{tabular}{|c|l|c|c|}
\hline № & \multicolumn{1}{|c|}{ Position } & $\begin{array}{c}\text { Number } \\
\text { of people }\end{array}$ & $\%$ \\
\hline 1 & Associate professor & 118 & 42,75 \\
\hline 2 & Senior lecturer & 42 & 15,22 \\
\hline 3 & Postgraduate student & 35 & 12,68 \\
\hline 4 & Teacher & 34 & 12,32 \\
\hline 5 & Technical staff & 33 & 11,96 \\
\hline 6 & Full professor & 14 & 5,07 \\
\hline & Total, people & 276 & 100 \\
\hline
\end{tabular}

energy saving in the social sphere, and supercomputer technologies are the scientific priorities defined within the program 5-100. Scientists of the Polytechnic Institute and the School of Electrical Engineering and Computer Science are representatives of these fields of science, and they want to familiarize themselves with the research of their foreign colleagues and share their own experience. This means that they also need solid skills in academic writing.

\section{Contingent of attendees of academic writing courses}

The attendees of academic writing courses are SUSU staff members: academic staff, postgraduate students, and technical staff. Table 2 shows the contingent of attendees according to their positions.

Table 2 indicates that associate professors show the greatest interest in academic writing courses. They make up more than $40 \%$ of the total number of course attendees. These are professionals who have already risen to a certain level on the scientific ladder, achieved certain results in their research and have considerable experience in publishing their works in Russian. At the present stage, they feel the need to improve their knowledge in the field of academic writing in English, in order to be able to present their research at the international level.

Staff members holding teaching positions, as well as postgraduate students, make up approximately the same percentage of the total number of attendees of academic writing courses, that is, about $12 \%$ in each group. This means their research and subsequently present it to the international scientific community.

The group of attendees who hold the positions of professors is the smallest part of the total number of attendees $-5.07 \%$. This can be explained by their great experience in foreign publication activities, on the one hand, and by a conservative attitude to the need of exchanging research results with the international community, on the other.

\section{Importance of academic writing courses}

Academic writing courses aim not only to familiarize authors with the publication requirements of foreign journals, but also to raise the level of their general academic literacy, including academic writing in Russian. Coherent expression of thoughts in a foreign language is impossible without the ability to correctly formulate them in the native language. Therefore, the OAW offers advanced training courses aimed at improving academic literacy in both Russian and English.

The programs implemented by the Office of Academic Writing in SUSU have been developed according to the methodological guidelines for preparing and formatting scientific articles in journals indexed in the international citation databases [11]. They involve materials of modern Russian and foreign manuals that help master the academic style of writing [12-16].

To date, OAW staff members have developed six advanced training programs. Each of them is developed for a certain set of attendees according to their priorities and level of English [8; 17].

1. English: a scientific paper.

The course workload is 72 hours. The course is provided in English. The main sections of the program are: the process of writing an article, scientific genres, the structure of a scientific article, lexical and grammatical features of the English scientific style, editing an article, and using the language for argumentation. The training results in practical work on writing an article in English and its editing. 


\section{English: the basics of academic literacy. Grammar and vocabulary.}

The course workload is 72 hours. The course is provided in Russian and English. Within the framework of this program, course attendees study the process of writing an article, scientific genres, the structure of a scientific article, the basics of academic literacy, and lexical and grammatical features of the English scientific style. After completing the course, attendees translate a part of their research into English according to the rules of the scientific style (Abstract, Introduction, Methods, Results and Discussion, Compilation of Glossary).

3. English: introduction to writing a paper.

The course workload is 36 hours. The course is provided in Russian and English. This program is intended for the attendees who have the minimum level of English. Attendees are familiarized with the process of writing an article, scientific genres, the structure of a scientific article, the content of each section, and the rules for composing a scientific text. Upon completion of the course, the attendees submit a scientific text written in Russian and structured according to the requirements of top rated foreign scientific editions.

4. English: scientific citation databases.

The course workload is 36 hours. The course is provided in Russian and English. Within the framework of this program, course attendees are familiarized with academic databases, taught to identify the key information in English articles and analyze articles of a similar topic as well as choose journals for their publications.

\section{English: publication strategy.}

The course workload is 36 hours. The course is provided in Russian and English. Course attendees are familiarized with the concept of publication strategy, taught to define and develop their own publication strategies, familiarized with an opportunity to increase the number of citations of their publications. The course results in choosing journals for their publications.

\section{English: training for tutors.}

The course workload is 36 hours. The course is provided in English. The courses for tutor training consider the issues of providing counseling servic- es to authors of scientific articles. In classroom, future tutors consider the problems encountered by authors and find the ways to solve them.

Having studied the number of attendees who completed a particular course, we can conclude about the most popular advanced training programs. Table 3 was made basing on the results of the study. It shows that $30.43 \%$ of the attendees completed the course "English: a scientific paper", $27.91 \%$ - "English: the basics of academic literacy. Grammar and vocabulary", and $15.58 \%$ "English: introduction to writing a paper".

The most popular programs were "English: a scientific paper" (72 hours) and "English: the basics of academic literacy. Grammar and vocabulary" (72 hours). This is due to their practical orientation and possibility to consider the details of writing a scientific paper in English on the basis of specific exercises.

In addition to full-time courses, the Office staff members developed trial versions of distance courses in academic writing, such as: "English: introduction to writing a paper" (developed by M. Chernysheva); "English: the basics of academic literacy. Grammar and vocabulary" (developed by E. Nenakhova and E. Donova); "English: a scientific paper" (developed by M. Tsytovich); "English: publication strategy" (developed by E. Nenakhova). Run-time versions of the above mentioned distance courses are available on the "Electronic SUSU" platform.

The 36-hour introduction course in writing a paper was developed from January 2017 to March 2019. The content of the distance course was approved within the framework of two fulltime academic writing courses held in 2017 and 2018. Its attendees are members of the SUSU academic staff. Fig. 1 shows the distance course "English: introduction to writing a paper".

The developed courses were not approved in their distance form because the funding of OAW educational services had been cut off (as of April 2019).

\section{Conclusion}

The results show that the academic writing courses imparted by the OAW at SUSU are most 


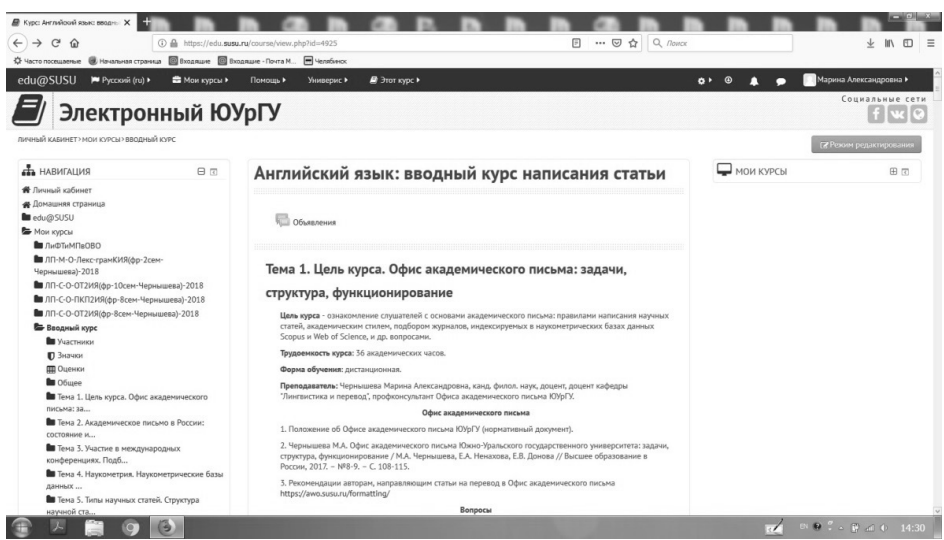

Fig. 1. Chernysheva M.A. English: introduction to writing a paper [platform https://edu.susu.ru/login/index.php]

Table 3

The number of attendees that completed the courses

\begin{tabular}{|c|l|c|c|}
\hline № & Advanced training programs & $\begin{array}{c}\text { Number } \\
\text { of people }\end{array}$ & $\%$ \\
\hline 1 & English: a scientific paper & 84 & 30,43 \\
\hline 2 & $\begin{array}{l}\text { English: the basics of academic } \\
\text { literacy. Grammar and } \\
\text { vocabulary }\end{array}$ & 77 & 27,91 \\
\hline 3 & $\begin{array}{l}\text { English: introduction to writing } \\
\text { a paper }\end{array}$ & 43 & 15,58 \\
\hline 4 & $\begin{array}{l}\text { English: scientific citation } \\
\text { databases }\end{array}$ & 40 & 14,49 \\
\hline 5 & English: publication strategy & 19 & 4,71 \\
\hline 6 & English: training for tutors & 13 & 6,88 \\
\hline & Total, people & 276 & 100 \\
\hline
\end{tabular}

popular among associate professors of socialhumanitarian and technical areas, i.e. those who have experience in publishing papers in Russian. More than $50 \%$ of the attendees opted for 72 hour practice-oriented programs that focus on the methodology for writing a scientific paper in English and improvement of language skills.

Positive feedback received from the attendees through oral and written surveys, as well as their increased foreign publication activities point to the successful implementation of the training programs developed by the OAW. It is noteworthy that upon completion of the academic writing courses in the analyzed period the attendees submitted 94 papers to journals and conference proceedings indexed in the scientific citation databases Scopus and Web of Science. Many of them had the first experience of foreign publication activity. The Office of Academic Writing assisted the authors in translating papers into English and proof-reading them by a native English speaker. The attendees' publication results require more detailed consideration in a separate study.

In our opinion, teaching of academic writing to the academic staff of SUSU should go beyond these advanced training programs. We find it promising to develop courses in academic English for specific purposes. Such courses will allow Russian-speaking authors to focus their attention on terminology bases and to get familiarized with the specifics of foreign publication activities in the relevant research field in more detail.

\section{References}

1. Korotkina, I.B. (2016). University Writing Centers in Russia: Goals and Prospects. Vysshee obrazovanie $v$ Rossii $=$ Higher Education in Russia. No. 1, pp. 75-86. (In Russ., abstract in Eng.)

2. Bazanova, E.M., Korotkina, I.B. (2017). Russian Writing Centers Consortium. Vysshee obrazovanie $v$ Rossii $=$ Higher Education in Russia. No. 4, pp. 50-57. (In Russ., abstract in Eng.)

3. The Russian Academic Excellence Project. The Ministry of Education and Science of the Russian Federation. Available at: https://5top100.ru/en/ about/more-about/

4. Smirnova, N.V. (2015). Fostering Academic Literacy and Academic Writing in University: From Theory to Practice. Vysshee obrazovaniev 
Rossii $=$ Higher Education in Russia. No. 6, pp. 58-64. (In Russ., abstract in Eng.)

5. Storseth, T. (2009). Teaching Academic Writing as a Cultural Bridge. In: 3rd International Technology, Education and Development Conference, Valencia, Spain, 9-11 March, 2009. Pp. 1493-1502. Available at: https://library.iated. org/view/STORSETH2009TEA

6. Šerić, M. (2017). Insights on Culture and Communication in Academic Settings. In: 11th International Technology, Education and Development Conference, Valencia, Spain, 6-8 March, 2017. Pp. 6996-7003. Available at: https://library.iated.org/view/SERIC2017INS

7. Casanovas Català, M. (2013). Writing 2.0: Internet Tools and Academic Writing. In: 5 th International Conference on Education and New Learning Technologies, Barcelona, Spain, 1-3 July, 2013. P. 3972 (abstract only). Available at: https://library.iated.org/view/CASANOVASCATALA2013WRI

8. Chernysheva, M.A., Nenakhova, E.A., Donova, E.V. (2017). Academic Writing Office of South Ural State University: Goals, Structure, Functioning. Vysshee obrazovanie $v$ Rossii $=$ Higher Education in Russia. No. 8/9 (215), pp. 108-115. (In Russ., abstract in Eng.)

9. Nenakhova, E., Seryapina, Y. (2017). Tutorship as an Element of Promoting Academic Literacy of the Academic and Teaching Staff: The Experience of the South Ural State University. In: 10th Annual International Conference of Education, Research and Innovation, Seville, Spain, 16-18 November, 2017. Pp. 1720-1724. Available at: https://library. iated.org/view/NENAKHOVA2017TUT

10. Nenakhova, E., Seryapina, Y. (2017). On-line Module in Academic Writing Course: Problems and Perspectives of Implementation. In: 10th Annual International Conference of Education, Research and Innovation, Seville, Spain, 16-18 November, 2017. Pp. 1714-1719. Available at: https://library. iated.org/view/NENAKHOVA2017ONL
11. Kirillova, O.V. (Ed). (2017). Guidelines in Preparing and Formatting Scientific Papers for Journals Indexed in International Scientometric Databases. Moscow, Association of scientific editors and publishers, 144 p. Available at: http://rasep.ru/ for-members/biblioteka-anri (In Russ.)

12. Hamp-Lyons, L., Heasley, B. (2008). Study Writing: A Course in Writing Skills for Academic Purposes. 2nd ed. Cambridge: Cambridge Univ. Press, $213 \mathrm{p}$.

13. Norris Brimley, C. (2018). Academic Writing in English. Language Services University of Helsinki, 85 p.

14. Wallwork, A. (2013). English for Academic Research: Grammar Exercises. New York: Springer Science+Business Media, 172 p.

15. Bogolepova, S., Gorbachev, V., Shadrova, E., Suchkova, S., Kuznetsova, L., Oschepkova, T., Ivanova, A., Pervukhina, I. (2015). English for Academics. Book 2: A Communication Skills Course for Tutors, Lecturers and PbD Students. In collaboration with the British Council. Cambridge: Cambridge University Press, $171 \mathrm{p}$.

16. Popova, N.G., Koptyaeva, N.N. (2016). Akademicheskoe pis'mo: stat' I IMRAD: uchebnoye posobie [Academic Writing: Papers in IMRAD. A Manual for Postgraduate Students and Researchers in Sciences]. Yekaterinburg: IFiP UrO RAN Publ., 160 p. (In Russ.)

17. Nenakhova, E., (2017). The Peculiarities of Academic Writing Training: Experience of the Academic Writing Center at NRU SUSU. In: $69^{t h} \mathrm{Sci}$ ence Conference Nauka YuUrGU, Chelyabinsk, Russia, 04-05 April, 2017. Pp. 603-608. (In Russ.)

Acknowledgements. The work was supported by Act 211 Government of the Russian Federation, contract \#02.A03.21.0011.

The paper was submitted 25.06.19

Received after reworking 27.08.19 Accepted for publication 02.09.19

\section{Обучение академическому письму на английском языке русскоязычных научно-педагогических работников (из опыта работы)}

Чернышева Марина Александровна - канд. филол. наук, доцент, преподаватель курсов академического письма. E-mail: chernyshevama@susu.ru

Козлова Анна Олеговна - преподаватель кафедры «Русский язык как иностранный», преподаватель курсов академического письма. E-mail: kozlovaao@susu.ru 
Аонова Евгения Валерьевна - администратор офиса академического письма. E-mail: donovaev@susu.ru

Южно-Уральский государственный университет (национальный исследовательский университет), Институт лингвистики и международных коммуникаций, Челябинск, Россия Aдрес: 454080, г. Челябинск, проспект Аенина, 76

Аннотачия. В данной статье рассматриваются предварительные результать обучения научно-педагогчческих работников Южно-Уральского государственного университета (начионального исследовательского университета) на курсах повышения квалификачии по академическому письму. Обучающие программы трудоёмкостью от 36 до 72 часов разработань учебно-методическим отделом Офиса академического письма, открытого в вузе В 2016 г. с челью совершенствования академической грамотности научно-педагогчческих работников университета, развития навыков профессиональной коммуникачии на английском языке, а также поддержки авторов, желаюших опубликовать свои работы в высокорейтинговых научных журналах, индексируемьх в наукометрических базах данных Scoриs $u$ Web of Science. B результате освоения этих программ авторы научных статей получают знания об основах академического писвма, структуре научной статьи, научном стиле и его лексических и грамматических особенностях в англииском языке, о редактировании статьи, а также о работе с наукометрическими базами данньх и особенностях публикачионной стратегии. По результатам исследования, проведённого в период с октябрл 2016 по декабрь 2018 г2., представлень статистические даннье об африлиачии слушателей (принадлежность к вузу), контингенте (занимаемая должность) и востребованности предлагаемых программ обучения (колччество слушателей, прошедших обучение по каждой из программ). Полученные даннье свидетельствуют об особом интересе к курсам со сторонь представителей сочиально-гуманитарных и технических дисииплин. Курсы академическо$2 о$ письма наиболее востребовань сотрудниками, работающими в должности доцента, имеюшими опьт публикационной деятельности на русском языке. Особый интерес у авторов вызывают интенсивные практико-ориентированные программы. После прохождения курсов слушателями поданы на рассмотрение в высокорейтинговые журналы и сборники конферениий научные статьи на английском языке, подготовленнье при поддержке Офиса академического письма. Образовательная деятельность Офиса академического письма может получить своё развитие в ходе разработки и реализачии новьх, в том числе дистанилонных, обучающих программ, показателем эффективности которых будет повышение публикачионной активности сотрудников вуза.

Ключевые слова: академическое письмо, публикачионная активность, научнал статья на англииском языке, наукометрические базы данных, Scopus, Web of Science

Аля ицитирования: Chernysheva, M.A., Kozlova, A.O., Donova, E.V. Teaching Academic English to Russian-speaking Academic Staff: The Case of the Office of Academic Writing // Высшеe образование в России. 2019. Т. 28. № 10. С. 50-57.

DOI: https://doi.org/10.31992/0869-3617-2019-28-10-50-57

Статья поступила в редакцию 25.06.19

После доработки 27.08.19

Принята к публикачии 02.09.19 